\title{
$\begin{array}{llllllllllllllll}\mathbf{S} & \mathbf{T} & \mathbf{U} & \mathbf{D} & \mathbf{I} & \mathbf{A} & \mathbf{I} & \mathbf{M} & \mathbf{A} & \mathbf{T} & \mathbf{E} & \mathbf{R} & \mathbf{I} & \mathbf{A} & \mathbf{L} & \mathbf{Y}\end{array}$
}

KWARTALNIK HISTORII KULTURY MATERIALNEJ 67 (2), 2019

PL ISSN 0023-5881

www.iaepan.edu.pl

DOI: 10.23858/KHKM67.2019.2.001

\author{
Iwona Wojciechowska
}

\section{Średniowieczne plakietki pielgrzymie i świeckie z badań w Stargardzie}

\begin{abstract}
Słowa kluczowe: Stargard, pielgrzymki, znaki pielgrzymie, plakietki świeckie, archeologia, późne średniowiecze
\end{abstract}

Key words: Stargard, pilgrimages, pilgrim badges, secular badges, archaeology, late Middle Ages

Życie średniowiecznych mieszkańców Europy wypełnione było różnymi praktykami związanymi ze sferą sacrum. Istotną formę religijności stanowiły pielgrzymki do grobów i miejsc przechowywania relikwii świętych, którzy byli pośrednikami między niebem i ziemią ${ }^{1}$ I choć zwyczaj udawania się do grobów pochodzi jeszcze z pierwszych wieków chrześcijaństwa, to dopiero od XII w. nastąpił rozkwit pątnictwa, które w okresie późnego średniowiecza stało się zjawiskiem masowym. Ruch pielgrzymkowy odegrał ogromną rolę w wielu dziedzinach życia średniowiecznego, ponieważ dla większości ludzi peregrynacja do ośrodków kultu była najważniejszą i często jedyną okazją do dalekiej podróży, poznania obcych krajów i ich mieszkańców². Pątnicy, chcąc doświadczyć realnego kontaktu z sacrum, przywozili pamiątki z odwiedzonych miejsc, m.in. ziemię z grobów świętych. Od XI w. zaczęli zaopatrywać się przy grobie św. Jakuba w Santiago de Compostela w muszle małż. Stały się one pierwowzorem dla plakietek, które już od połowy XII w. dostępne były także w innych ośrodkach. Średniowieczne znaki pątnicze to w większości niewielkich rozmiarów, odlewane w kamiennych formach plakietki ze stopu cyny i ołowiu, zaopatrzone po bokach w oczka, które służyły do zamocowania. Emblematy przedstawiały głównie świętych, z którymi związane były cele pielgrzymek ${ }^{3}$.

W przeciwieństwie do znaków pątniczych plakietki świeckie, choć wykonane $\mathrm{z}$ tego samego surowca i tą samą metodą, a często nawet produkowane przez tych samych rzemieślników, niosły zupełnie inne przesłanie. Jednoznacznym ideom sacrum emblematów pątniczych przeciwstawiały bardziej zróżnicowaną symbolikę nawiązującą do świeckich aspektów życia.

Sześć takich przedmiotów odkryto podczas zakończonych w 2018 r. badań archeologicznych prowadzonych w Stargardzie, na części tzw. XXVIII kwartału Starego Miasta (ryc. 1). Prace objęły pięć nieistniejących współcześnie działek — Schuhstrasse 439-4434. Podczas prowa-

1 Vauchez A. 1987, s. 393, 423; Starnawska M. 2008, s. 18. Kult świętych i ich relikwii jest jedną z ważnych cech późnośredniowiecznej religijności, Vauchez A. 1987, s. 393; Starnawska M. 2008, s. 11.

2 Köster K. 1984, s. 203; Witkowska A. 1995, s. 12; Rębkowski M., Simiński R. 2010, s. 145; Majewski M., Rębkowski M., Simiński R. 2016, s. 129.

3 Köster K. 1984, s. 206; Kuczyński S.K. 1995, s. 321-322; Haasis-Berner A., Poettgen J. 2002, s. 174-175; Rębkowski M. 2004, s. 154-155; Paner H. 2016, s. 36.

${ }^{4}$ Stań K. 2018, s. 222, 224. Prace prowadzone były od 2015 r. przez pracowników Działu Archeologii Muzeum Archeologiczno-Historycznego w Stargardzie, przy udziale studentów archeologii Uniwersytetu Szczecińskiego oraz Uniwersytetu im. Adama Mickiewicza w Poznaniu. Teren badań znajdował się w obrębie miasta 

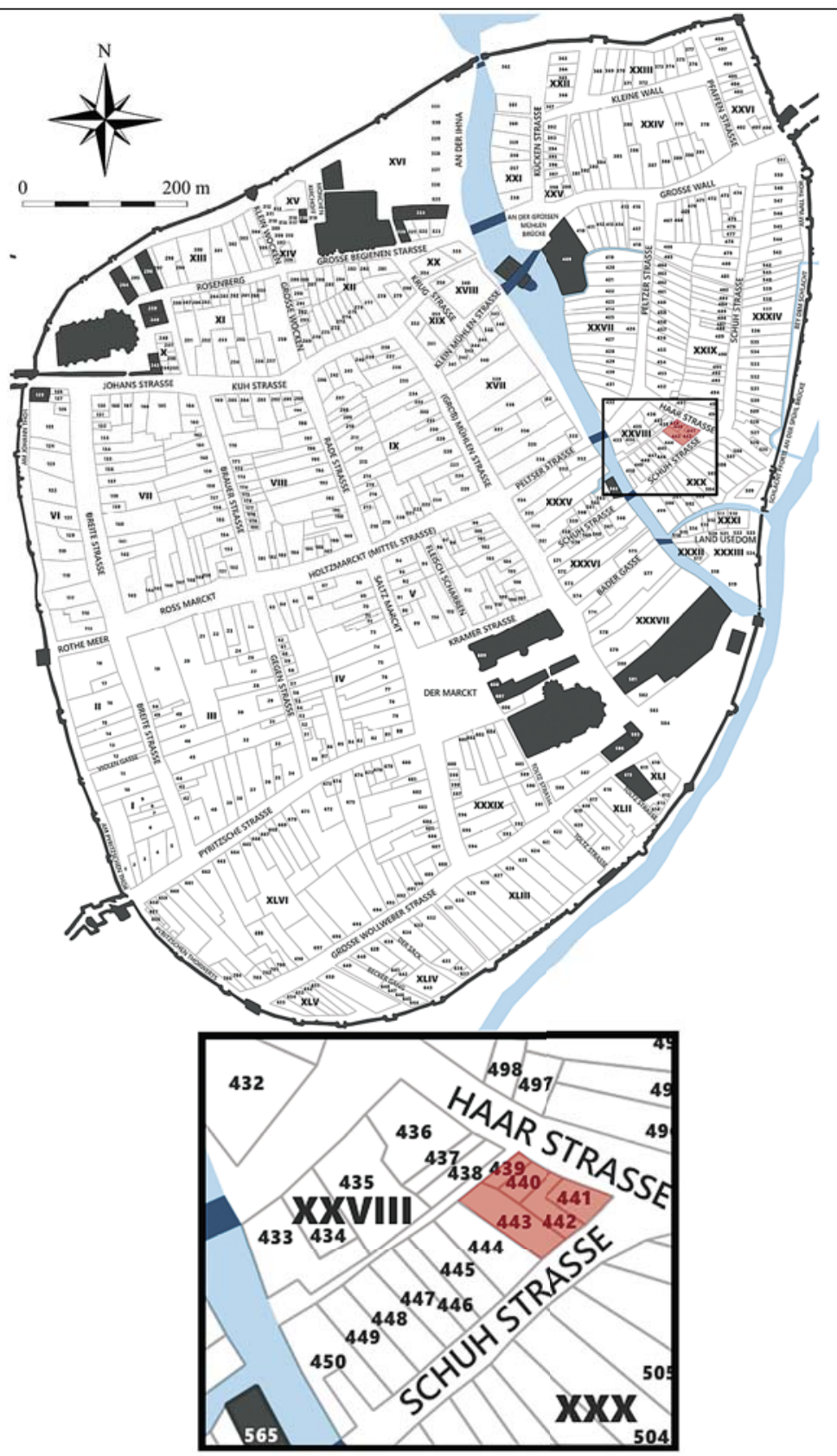

Ryc. 1. Stargard, Stare Miasto. Plan miasta według M.F. Schwedtkena z 1724 r. z zaznaczonym terenem badań w części tzw. kwartału XXVIII. Oprac. I. Wojciechowska, rys. M. Szeremeta

Fig. 1. Stargard, the Old Town. A 1724 town plan after M. F. Schwedtken, with an indication of the excavation site in the so-called quarter XXVIII. Compiled by I. Wojciechowska, drawn by M. Szeremeta 
dzonych badań natrafiono na dwie plakietki pielgrzymie, jeden emblemat świecki oraz trzy znaki, których symbolika jest niejednoznaczna. Obszar przy obecnej ul. Włosienniczej został zasiedlony zaraz po lokacji miasta, w połowie XIII w. i właśnie w najstarszych warstwach użytkowych na tym terenie, w obrębie prywatnych działek miejskich odkryte zostały wszystkie omówione poniżej zabytki.

Pierwsza prostokątna plakietka zwieńczona półkolem ma wymiary $2,3 \times 4,1 \mathrm{~cm}$, a po bokach cztery oczka do mocowania (ryc. 2:1). Reliefowe przedstawienie figuralne ukazuje postać biskupa w mitrze. W prawej ręce trzyma on symbol swej władzy — pastorał, natomiast w lewej — odwrócony do góry klucz. Druga strona plakietki ma wzór kraty. Znak ten pochodzi z sanktuarium w Maastricht, a przedstawiony na nim biskup to św. Serwacy. Serwacy urodził się na Wschodzie ${ }^{5}$, przed 345 rokiem i był jednym z najwybitniejszych teologów IV w. To on przeniósł biskupstwo z limburskiego Tongern do Maastricht, gdzie w 384 r. zmarł i został pochowany ${ }^{6}$. Kult tego świętego udokumentowany jest już w VI stuleciư ${ }^{7}$, jednak masowe pielgrzymki wiernych do jego grobu rozpoczęły się dopiero w drugiej połowie XII w. Pierwsze emblematy pątnicze (pochodzące być może już z końca XII w.) przedstawiają go w szatach pontyfikalnych $\mathrm{z}$ pastorałem w jednej i kluczem w drugiej ręce ${ }^{8}$. Serwacy przed przeniesieniem biskupstwa udał się z pielgrzymką do Rzymu. Nawiedzając tam grób św. Piotra, miał otrzymać od niego jeden z kluczy ${ }^{9}$ do królestwa niebieskiego, a wraz z nim moc zapewnienia życia wiecznego wszystkim, którzy o to proszą ${ }^{10}$. Otrzymany od klucznika bram niebieskich przedmiot miał zostać odnaleziony w grobie Serwacego w VIII w. ${ }^{11}$, natomiast po raz pierwszy jako atrybut świętego w źródłach pisanych wymieniany jest w latach 1066-1070 $0^{12}$. O ogromnej popularności kultu biskupa Maastricht świadczy duża liczba różnych wariantów znaków z jego postacią odnajdywanych w całej Europie i datowanych jeszcze na wiek XIII ${ }^{13}$.

Emblematy z analogicznym jak ze Stargardu przedstawieniem św. Serwacego znalezione zostały też w innych częściach Europy, na północnych wybrzeżach Morza Północnego i Bałtyku oraz na Śląsku, m.in. w Bremie ${ }^{14}$, Coudorpe ${ }^{15}$, Dordrechcie ${ }^{16}$, Greifswaldzie ${ }^{17}$, Malchinie ${ }^{18}$ i Wrocławiu ${ }^{19}$. Pochodzą one z okresu od drugiej połowy XIII do pierwszej połowy XIV w. ${ }^{20}$

lokacyjnego, wpisanego do rejestru zabytków pod nr 40, decyzją KL.-V-0/19/55 z dnia 22.04.1955 r. i objętego ochroną jako stanowisko archeologiczne Stargard 11 (AZP 32-10/166). Numeracja kwartału i parcel pochodzi z katastru miasta Stargard stworzonego przez Martina F. Schwadtkena w 1724 r.

5 Według jednej z legend Serwacy miał pochodzić z Ziemi Świętej, por. Beuningen H.J.E., Koldeweij A.M. 1993, s. 192.

${ }^{6}$ Beuningen H.J.E., Koldeweij A.M. 1993, s. 192; Wittstock J. 1998, s. 97; Haasis-Berner A. 2003, s. 180; Rębkowski M. 2004, s. 161.

${ }^{7}$ Haasis-Berner A. 2003, s. 180. Według Mariana Rębkowskiego kult rozpoczął się już w V w., por. Rębkowski M. 2004, s. 161.

${ }^{8}$ Rębkowski M. 2004, s. 161.

${ }^{9}$ Klucz ten według tradycji do dziś przechowywany jest w bazylice p.w. św. Serwacego w Maastricht, Wittstock J. 1998, s. 97; Haasis-Berner A. 2003, s. 180; Spencer B. 2010, s. 269.

${ }^{10}$ Beuningen H.J.E., Koldeweij A.M. 1993, s. 192; Wittstock J. 1998, s. 97; Spencer B. 2010, s. 269.

11 Haasis-Berner A. 2003, s. 180.

12 Koldeweij J. 1985, s. 66.

13 Beuningen H.J.E., Koldeweij A.M. 1993, s. 192; Haasis-Berner A. 2003, s. 181.

14 Köster K. 1984, s. 204; Wittstock J. 1998, s. 98; Rech M. 2004, s. 310.

15 Haasis-Berner A. 2003, s. 184, nr 04348, http://www.kunera.nl/Kunerapage.aspx.

16 Haasis-Berner A. 2003, s. 184, nr 05311, http://www.kunera.nl/Kunerapage.aspx.

17 Schäfer C. 2015, s. 339.

18 Jänicke R., Schanz E. 2013, s. 493.

19 Sawicki J., Wachowski K. 2018, s. 725, ryc. 659a.

${ }^{20}$ Wittstock J. 1998, s. 98; Rech M. 2004, s. 310; Jänicke R., Schanz E. 2013, s. 493; Schäfer C. 2015, s. 339; Sawicki J., Wachowski K. 2018, s. 729-730; baza danych "Kunera". 
Datowanie to pokrywa się z datą próby dendrochronologicznej z dębowego drewna pobranego z warstwy użytkowej, w której odnaleziona została plakietka w Stargardzie; czas ścięcia tego drzewa określono na rok $1294(-7 /+9)^{21}$.

Kolejny znak o charakterze pątniczym, o kształcie prostokąta zwieńczonego trzema wieżami, ma maksymalne wymiary $3,2 \times 4 \mathrm{~cm}^{22}$ (ryc. 2:2). Pierwotnie zapewne zaopatrzony był w cztery oczka do przytwierdzenia do odzieży, jednak zachowały się pozostałości po dwóch z nich. Zabytek przedstawia scenę Pokłonu Trzech Króli. Po lewej stronie ukazana jest Maryja siedząca na wprost i trzymająca na lewym kolanie Jezusa. Jej głowę zdobi korona. Po prawej stronie postacie mędrców pokazane są w rytualnym hołdzie, w układzie hellenistycznym. W zgiętych ramionach królowie trzymają dary. Środkowa wieża górująca nad pozostałymi podtrzymywana jest przez dwa proste łęki oporowe. Tył plakietki pokryty jest motywem kraty.

Odkryty emblemat związany jest z kultem relikwii Trzech Króli w Kolonii, który wykształcił się po roku 1164, gdy Fryderyk I Barbarossa przekazał szczątki Mędrców ze Wschodu przechowywane dotychczas w Mediolanie arcybiskupowi kolońskiemu - Raynaldowi von Dasselowi. Ze względu na potrzebę godnego miejsca dla złożenia relikwii w 1248 r. rozpoczęto budowę katedry w stylu gotyckim ${ }^{23}$. W tym też czasie Kolonia, obok Rzymu, Santiago de Compostela i Canterbury, stała się głównym celem pielgrzymek pokutnych i jednym z ważniejszych miejsc peregrynacji wiernych ${ }^{24}$. Analizowana plakietka należy do typu A II według typologii zaproponowanej przez Andreasa Haasis-Bernera i Jörga Poettgena ${ }^{25}$. Badacze określili produkcję znaków kolońskich o tym wariancie na czas od 1248 r. do połowy XIV w. ${ }^{26}$ To bardzo szerokie ramy chronologiczne, które w przypadku stargardzkiego znaleziska można zawęzić dzięki pobranym próbom z drewna odkrytego w tej samej warstwie użytkowej, co koloński emblemat. Data ścięcia drzewa to rok $1276^{27}$. Wraz z kontekstem pozostałych znalezisk pozwala ona określić datowanie zabytku ze Stargardu na przełom XIII i XIV w.

Sanktuaria w Maastricht i Kolonii były jednymi z najważniejszych celów pielgrzymek wiernych w Niemczech w późnym średniowieczu ${ }^{28}$. Spośród zarejestrowanych na Pomorzu Zachodnim dziewięciu znaków pątniczych ${ }^{29}$, cztery pochodzą właśnie z tych dwóch miejsc ${ }^{30}$. Dwie plakietki z Kolonii i dwa emblematy związane z kultem św. Serwacego, a także źródła pisane o ruchu pielgrzymkowym ludności Pomorza Zachodniego do grobu biskupa Maastricht ${ }^{31}$, są dowodami na popularność tych sanktuariów.

Pozostałe cztery znaleziska mają charakter świecki. Plakietka w kształcie trójkąta o bokach $3 \times 3,5 \times 3,5 \mathrm{~cm}$ (ryc. $2: 3$ ) ma tylko ślady po uchwycie do zamocowania. Jej kształt i symbolika wskazują, że może to być element uprzęży końskiej. Nie tylko rycerze nosili bowiem znaki heraldyczne i inne emblematy rozpoznawcze. Wierzchowce również zdobione były herbowymi odniesieniami do właściciela lub jeźdźca. Zawieszki heraldyczne na uprzężach końskich, ale

21 Krąpiec M. 2018.

22 Wysokość środkowej, najwyższej wieży.

${ }^{23}$ Haasis-Berner A. 2003, s. 169; Paner H. 2016, s. 241.

${ }_{24}$ Rębkowski M. 2004, s. 161; Spencer B. 2010, s. 261.

${ }^{25}$ Haasis-Berner A., Poettgen J. 2002.

${ }^{26}$ Haasis-Berner A., Poettgen J. 2002, s. 182-183.

27 Krąpiec M. 2018.

${ }_{28}$ Rębkowski M. 2004, s. 161; Spencer B. 2010, s. 261; Rębkowski M. 2014, s. 21.

29 Trzy znalezione zostały podczas bagrowania Odry i Parsęty, dwa w Kołobrzegu, jeden odkryto w Szczecinie, jeden w Koszalinie i jeden w Stargardzie, por. Majewski M., Rębkowski M., Simiński R. 2016, s. 141. Ostatni, dziewiąty zabytek pochodzi ze Stargardu, a jego funkcja jako odznaki pielgrzymiej obecnie jest domniemana, Janowski A. 2017, s. 131.

${ }^{30}$ Znak św. Serwacego z Kołobrzegu oraz emblemat z wizerunkiem św. Urszuli odkryty na Podzamczu w Szczecinie, Rębkowski M. 1998, s. 224-225; Rębkowski M., Rulewicz M. 2001.

31 Heyden H. 1940, s. 15. 


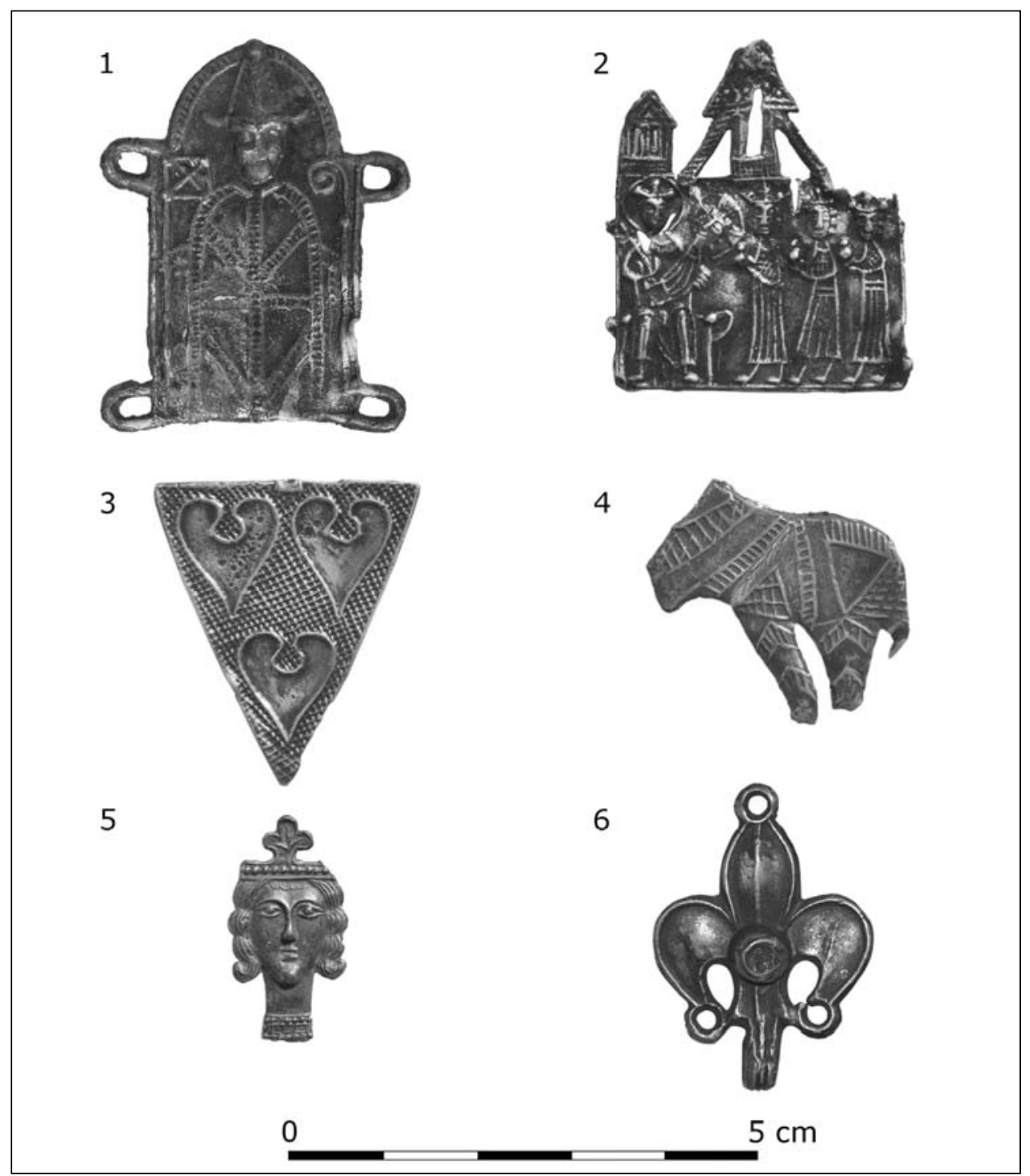

Ryc. 2. Stargard, Stare Miasto. Znaki pielgrzymie i świeckie. Fot. i oprac. M. Szeremeta

Fig. 2. Stargard, the Old Town. Pilgrim badges and secular badges. Photographed and compiled by M. Szeremeta

koliste, po raz pierwszy zastosowano w XII w. ${ }^{32}$ Omawiany przedmiot ozdobiony został reliefowym przedstawieniem trzech figur w układzie 2 i 1, znajdujących się w dwóch poziomach, $\mathrm{w}$ formie serc $\mathrm{z}$ trójlistnymi wycięciami u góry. Są to heraldyczne przedstawienia lilii wodnych ${ }^{33}$. Symbol ten związany jest z hrabiami Brehny (Saksonia) ${ }^{34}$.

${ }^{32}$ Mills N. 2003, s. 62; Koldeweij J. 2006, s. 37.

33 Znamierowski A. 2017, s. 237.

${ }^{34}$ Posse O. 1888, s. 7. 
Margrabia Konrad Wielki z rodu Wettynów podzielił swoje rozległe posiadłości między pięciu synów, w konsekwencji czego najmłodszy z nich, Fryderyk I, otrzymał hrabstwo Brehny ${ }^{35}$. Najstarszym zachowanym wizerunkiem pieczęci hrabiów Brehny jest okrągły stempel z przedstawieniem gryfa z 1208 r. ${ }^{36}$ Sygnował się nim wnuk Konrada Wielkiego - Fryderyk II. Dopiero jego potomkowie, w latach dwudziestych XIII w., po raz pierwszy wykorzystali symbol trzech lilii wodnych ${ }^{37}$, które stały się elementem dziedzicznym w rodowym herbie aż do wygaśnięcia dynastii wraz z Ottonem III w 1290 r. Wówczas to, za sprawą króla niemieckiego Rudolfa I, władztwo nad Brehną przeszło w ręce jego wnuka, także Rudolfa, księcia Saksonii z dynastii askańskiej ${ }^{38}$. Zgodnie z ówczesnym zwyczajem nowy hrabia Brehny, choć nie był spokrewniony z poprzednim rodem, w swojej pieczęci z początku XIV w. użył symbolu tarczy ozdobionej trzema wodnymi liliami ${ }^{39}$.

Plakietka z herbem hrabstwa Brehny odkryta została w warstwie użytkowej, z której pobrano próbę do analizy dendrochronologicznej. Na tej podstawie wykazano, że drzewo ścięto w $1281 \mathrm{r}^{40}$ Podobną trójkątną zawieszkę, w kształcie tarczy herbowej z trzema sercami w analogicznym układzie jak na znalezisku ze Stargardu, odkryto w Stralsundzie w roku 2012. Datowanie tego ostatniego zabytku określono na ok. $1300 \mathrm{roku}^{41}$. Wydaje się jednak, że zdeponowanie emblematu herbowego ze Stargardu miało miejsce na początku XIV stulecia. Wówczas to poświadczone są bezpośrednie kontakty Księstwa Pomorskiego z Księstwem Saksonii-Wittenbergi ${ }^{42}$. Prawdopodobnie również omawiane znalezisko $\mathrm{z}$ herbem hrabstwa Brehny należy wiązać z kontaktami handlowymi, które przetrwały aż do okresu nowożytnego. Potwierdzeniem tego założenia mogą być inne zabytki tej proweniencji odkrywane na badanych parcelach ${ }^{43}$.

Wśród znaków odkrytych w Stargardzie są także dwa fragmenty plakietek trudne do identyfikacji. Jeden z zabytków, o nieregularnym kształcie i maksymalnych wymiarach $2,9 \times 2,8 \mathrm{~cm}$, zdobiony jest ornamentem kraty, kreskowaniem oraz wzorami geometrycznymi (ryc. 2:4). Być może to kropierz, którym przykryty był wierzchowiec, a zaakcentowany na nim trójkąt przedstawia tarczę. Zachowany ułamek znaku może być zarówno fragmentem emblematu pielgrzymiego ${ }^{44}$, jak i świeckiego o tematyce rycerskiej. Przedmiot znaleziono w warstwie użytkowej z początku XIV w.

Druga niekompletna plakietka w kształcie ludzkiej głowy ma maksymalne wymiary $1,3 \times 2,4 \mathrm{~cm}$ (ryc. 2:5). Znak uległ uszkodzeniu, wskutek czego brakuje reszty postaci poniżej szyi. Zachowana głowa przedstawiona jest $\mathrm{w}$ diademie $\mathrm{z}$ czterema puklami falowanych włosów po bokach twarzy. Brak zarostu może wskazywać, że jest to kobieta ${ }^{45}$. Zabytek odkryty został

35 Streich B. 2003, s. 216.

36 Posse O. 1888, tabl. IX.9.

37 Posse O. 1888, tabl. X.

38 Posse O. 1893, s. 8-9; Assing H. 2003, s. 36.

39 Posse O. 1893, s. 10, tabl. XXVIII.4.

40 Krapiec M. 2018.

41 Brüggemann S. 2013, s. 540.

42 Zarówno w hrabstwie Brehny, jak i w sąsiadującej z Pomorzem Nowej Marchii, władzę sprawowali wówczas margrabiowie z dynastii askańskiej. W związku z tym po śmierci margrabiego Waldemara w 1319 r., o prawa do Marchii Brandenburskiej (z tytułu pokrewieństwa po mieczu) ubiegał się Rudolf — książe elektor saski, a zarazem i hrabia Brehny. Spór o władzę zaowocował konfliktem księcia saskiego z pomorskimi Gryfitami, Rymar E. 2015, s. 283-287.

${ }^{43}$ Podczas prac m.in. natrafiono na fragmenty kafli i naczynia kamionkowe, Majewski M. 2017, s. 13711372.

${ }^{44}$ Niektórzy święci przedstawiani są na znakach konno, m.in. Tomasz Becket, Hubert, Jerzy oraz Marcin. Postać jeźdźca jest również elementem większej kompozycji plakietki, jak np. ażurowe znaki z przedstawieniem Pokłonu Trzech Króli oraz Świętej Krwi z sanktuarium w Schwerinie, Paner H. 2016, s. 147, nr kat. 5024; s. 251, nr kat. 2191.

45 Znane są znaki przedstawiające głowę Karola Wielkiego z brodą i koroną, Beuningen H.J.E., Koldeweij A.M. 1993, s. 175. 
w warstwie użytkowej, z której pozyskano również dwie monety z końca XIII i początku XIV w. — denar brandenburski Ottona IV, Ottona V lub innego margrabiego ze starszej bądź młodszej linii z ok. $1295 \mathrm{r}^{46}$ oraz brakteat meklemburski datowany na lata $1280-1325^{47}$.

Interpretacja ostatniego $\mathrm{z}$ prezentowanych emblematów stanowi największy problem. Choć zachował się on w całości, jego symbolika nie jest jednoznaczna. Plakietka o wymiarach $2,4 \times 3,3 \mathrm{~cm}$ to heraldyczny kwiat lilii (franc. fleur-de-lys) (ryc. 2:6). Ramiona znaku zakończone są otworami do mocowania, natomiast dolną część zagięto do tyłu, tworząc haczyk. W centrum odznaki znajduje się wgłębienie na oczko, zapewne ze szkła. Emblemat znaleziony został w warstwie użytkowej z przełomu XIII i XIV w. wraz z fragmentem plakietki przedstawiającym ludzką głowę ${ }^{48}$.

Lilia symbolizuje niewinność i czystość, dlatego często kojarzona jest z osobą Matki Bożej i Zwiastowaniem Pańskim ${ }^{49}$. Aplikacje w kształcie lilii, analogiczne do odkrytej w Stargardzie odznaki, znalezione w Londynie Michael Mitchiner przypisał jednemu z angielskich sanktuariów maryjnych - w Walsingham ${ }^{50}$. Niestety to jedyne informacje łączące tego typu znaki z konkretnym miejscem pielgrzymkowym. Brak podstaw, by odznakę ze Stargardu w kształcie heraldycznej lilii przypisać ośrodkowi w Walsingham ${ }^{51}$. W świeckim kontekście fleur-de-lys to częsty element herbów francuskich rodów królewskich i arystokratycznych, zaś już w XIII w. — motyw dekoracyjny na małych aplikacjach zdobiących strój ${ }^{52}$. Wydaje się jednak, że odkryta w Stargardzie plakietka nie należy do takiej kategorii zabytków. Świadczy o tym choćby dolna część znaku zakończona haczykiem zagiętym do tyłu, na którym być może zawieszano medaliony lub ampułki ${ }^{53}$.

Wszystkie prezentowane powyżej emblematy znaleziono w Stargardzie w obrębie przestrzeni prywatnych działek miejskich, w warstwach użytkowych. Dotychczas jedyny przedmiot będący bez wątpienia pielgrzymią plakietką odkryto w przestrzeni publicznej na Rynku Staromiejskim $^{54}$. Tak zwany kwartał XXVIII to obrzeże miasta lokacyjnego, dzielnica przymurna, którą zamieszkiwali rzemieślnicy o średnim statusie społecznym, m.in. skórnicy, szewcy i garbarze, a więc nie najbogatsi mieszkańcy ${ }^{55}$. Kontekst znalezienia omawianych znaków pątniczych może wskazywać, że były one przedmiotami osobistej dewocji, być może częścią ołtarzyków domowych.

Odkryte emblematy pielgrzymie z badań przy ul. Włosienniczej pochodzą z najstarszych warstw osadniczych na tym terenie, datowanych na przełom XIII i XIV w. Teren ten zasiedlony został praktycznie zaraz po lokacji miasta, w połowie XIII w., a znaki należały zapewne do pierwszych kolonistów przybyłych z Zachodu. W związku z tym ciekawa, lecz niestety niemoż-

${ }^{46}$ Dannenberg H.-D. 1997, s. 105, nr kat. 125.

${ }^{47}$ Za pomoc w identyfikacji brakteatu dziękuję panu mgr. Grzegorzowi Śnieżko z IAE PAN.

${ }^{48}$ Analogiczny zabytek w kształcie lilii, datowany na lata 1260-1290, znajduje się na wystawie w Pommersche Landesmuseum w Greifswaldzie.

49 Spencer B. 2010, s. 157.

50 Mitchiner M. 1986, s. 35.

${ }^{51}$ W archiwach Bazyliki Sanktuarium Matki Bożej w Walsingham oraz w miejscowych zbiorach zabytków brak dowodów, że znak lilii heraldycznej był kiedykolwiek symbolem sanktuarium. Informacje te autorka uzyskała od archiwisty sanktuarium w Walsingham oraz kuratora „Sibley Collection”, Timothego McDonalda.

52 Egan G., Pritchard F. 2008, s. 201; Spencer B. 2010, s. 157; Kaute P., Rütz T., Samariter R. 2013, s. $478-479$, ryc. $177: 7$.

53 Por. Mitchiner M. 1986, s. 35.

54 Janowski A. 2017, s. 130-131.

55 Majewski M., Stań K. 2015, s. 3-6. 
liwa do rozwiązania jest kwestia, czy wybór celu peregrynacji związany był z ówczesną popularnością niemieckich sanktuariów ${ }^{56}$, czy też raczej z miejscem pochodzenia pierwszych stargardzkich osadników? Być może podróże do Maastricht i Kolonii, skąd pochodzą odkryte tu i tak wcześnie datowane plakietki, w ogóle nie odbyły się ze Stargardu, a znaki te należały do kolonistów i wraz z nimi dotarły na te tereny jako elementy indywidualnego kultu.

Dotychczas na terenie Pomorza Zachodniego znaleziono łącznie osiem plakietek pielgrzymich $^{57}$. Odkryte ostatnio w Stargardzie dwie odznaki pątnicze w znacznym stopniu poszerzają zatem katalog znalezisk z tego terenu. Są one niewiele młodsze od najstarszych odznak z miejsc świętych zlokalizowanych na obszarze między Renem i Mozą, a odkrytych w miastach hanzeatyckich takich jak Lubeka, Stralsund, Rostock lub Tallinn ${ }^{58}$. Plakietki z Kolonii i Maastricht mogą świadczyć o bardzo wczesnych peregrynacjach stargardzian, bo na przełomie stuleci XIII i XIV. Do czasu badań przy ul. Włosienniczej znane były źródła potwierdzające pielgrzymki ze Stargardu dopiero w wieku XV. Mowa tu o plakietce pielgrzymiej z Odilienbergu w Alzacji, odlanej na dzwonie z nieistniejącego kościoła filialnego w Rogowie, w powiecie stargardzkim, który obecnie znajduje się w wieży świątyni parafialnej p.w. św. Jana Chrzciciela w Stargardzie. Dzwon został odlany w drugiej połowie XV w. i udekorowany ażurową plakietą z wyobrażeniem św. Otylii ${ }^{59}$. Z tego okresu pochodzą też wiadomości ze źródeł pisanych o odwiedzaniu przez mieszkańców Stargardu Jerozolimy (w XV w.) oraz sanktuarium św. Teobalda w Thann ${ }^{60}$ (na początku XV w.).

Temat świeckich emblematów w Stargardzie jest wciąż nowy. Liczba znalezisk tego typu z obszaru miasta jest znikoma, jednakże sukcesywnie przybywa ich opracowań, chociaż przede wszystkim o charakterze informacyjnym. Tylko w przypadku przedmiotów z badań na Rynku Staromiejskim oraz w kościele augustianów przeprowadzono głębszą analizę ${ }^{61}$. W związku $\mathrm{z}$ tym, na obecnym etapie prac nie jest możliwe rozpatrywanie opisanego tu znaku herbowego w szerszym kontekście.

Adres Autorki:

mgr Iwona Wojciechowska

Muzeum Archeologiczno-Historyczne w Stargardzie

Rynek Staromiejski 2-4

73-110 Stargard

i.wojciechowska@muzeum-stargard.pl

ORCID: 0000-0002-1685-273X

\section{Bibliografia}

Assing Helmut. 2003. Askanier, [w:] Höfe und Residenzen im spätmittelalterlichen Reich. Ein dynastisch-typographisches Handbuch, t. 15.I, red. W. Paravicini, Tübingen, s. 31-37.

${ }^{56}$ Od XII w. zarówno Maastricht, jak i Kolonia, były jednymi z najważniejszych miejsc na pielgrzymkowej mapie Niemiec. Duża liczba znaków z sanktuariów z niemieckojęzycznego terenu między Renem i Mozą odnajdywana jest w regionie nadbałtyckim, Rębkowski M. 2004, s. 161; Spencer B. 2010, s. 261; Rębkowski M. 2014, s. $19-21$.

57 Jest ich dziewięć, jeśli doliczyć zabytek o niepewnej funkcji z Rynku Staromiejskiego w Stargardzie.

58 Rębkowski M. 2014, s. 21.

59 Majewski M. 2007, s. 20-21; Majewski M. 2010, s. 56-58.

${ }^{60}$ Boehmer F. 1903, s. 353; Rębkowski M., Simiński R. 2010, s. 150.

${ }_{61}$ Majewski M. 2013, s. 351, 358; Janowski A. 2016, s. 297-298; Janowski A., Stań K. 2016, s. 489; Janowski A. 2017, s. 132. 
Beuningen Hendrik Jan Engelbert van, Koldeweij Adrianus Maria. 1993. Catalogus, [w:] Heilig en Profaan. 100 Laatmiddeleeuwse Insignes, Rotterdam Papers, t. 8, red. H.J.E. van Beuningen, A.M. Koldeweij, Cothen, s. 115-323.

Boehmer F[elix]. 1903. Geschichte der Stadt Stargard i. Pomm., Geschichte der Stadt im Mittelalter, t. 1, Stargard i. Pomm.

Brüggemann Stefanie. 2013. Stralsund, Hansestadt, Lkr. Vorpommern-Rügen Fpl. 216, „Bodendenkmalpflege in Mecklenburg-Vorpommern", t. 60, s. 540-544.

Dannenberg Hans-Dieter. 1997. Die brandenburgischen Denare des 13. und 14. Jahrhunderts. Typenkatalog, Prägezeiten, Historische Zusammenhänge, Berlin.

Egan Geoff, Pritchard Frances. 2008. Dress accessories c. 1150-c. 1450, Medieval finds from excavation in London, t. 3, Woodbridge.

Haasis-Berner Andreas, Poettgen Jörg. 2002. Die mittelalterlichen Pilgerzeichen der Heiligen Drei Könige ein Beitrag von Archäologie und Campanologie zur Erforschung der Wallfahrt nach Köln, „Zeitschrift für Archäologie des Mittelalters”, t. 30, s. 173-202.

Haasis-Berner Andreas. 2003. Pilgerzeichen des Hochmittelalters, Würzburg.

Heyden Hellmuth. 1940. Das Wallfahrtswesen in Pommern, „Blätter für Kirchengeschichte Pommerns", z. 22/23, s. 7-21.

Janowski Andrzej. 2016. Zabytki metalowe, [w:] Archeologia Stargardu. Badania na obszarze dawnego kościoła augustiańskiego, Archeologia Stargardu, t. 2, cz. 2, red. M. Majewski, Stargard, s. $293-355$.

Janowski Andrzej. 2017. Przedmioty metalowe, [w:] Archeologia Stargardu. Badania na Rynku Staromiejskim. Archeologia Stargardu, t. 3, red. M. Majewski, K. Stań, Stargard, s. 127-157.

Janowski Andrzej, Stań Karolina. 2016. Stargard, miasto, okolice, „Stargardia”, t. 10, s. 489.

Jänicke Ralf, Schanz Elke. 2013. Malchin, Lkr. Mecklenburgische Seenplatte Fpl. 173, „Bodendenkmalpflege in Mecklenburg-Vorpommern”, t. 60, s. 493.

Kaute Peter, Rütz Torsten, Samariter Renate. 2013. Greifswald, Hansestadt, Lkr. Vorpommern-Greifswald Fpl. 193, „Bodendenkmalpflege in Mecklenburg-Vorpommern”, t. 60, s. 466-479.

Koldeweij Jos. 1985. Der gude Sente Servas. De Servatiuslegende en de Servatiana: een onderzoek naar de beeldvorming rond een heilige in de middeleeuwen, Assen-Maastricht.

Koldeweij Jos. 2006. Geloof \& Geluk. Sieraad en devotie in middeleeuws Vlaanderen, Arnheim.

Köster Kurt. 1984. Mittelalterliche Pilgerzeichen, [w:] Wallfhart kennt keine Grenzen. Themen zu einer Ausstellung des Bayerischen Nationalmuseum und des Adalbert Stifter Vereins, München, red. L. Kriss-Rettenbeck, G. Möhler, München, s. 203-224.

Krąpiec Marek. 2018. „Wyniki analizy dendrochronologicznej prób drewna z badań prowadzonych przez Muzeum Archeologiczno-Historyczne w Stargardzie, woj. zachodniopomorskie”, Kraków, maszynopis w archiwum Działu Archeologii MAH w Stargardzie.

Kuczyński Stefan K. 1995. Znaki pielgrzymie, [w:] Peregrinationes. Pielgrzymki w kulturze dawnej Europy, red. H. Manikowska, H. Zaremska, Warszawa, s. 321-327.

Majewski Marcin. 2007. Świadectwa pielgrzymek średniowiecznych mieszkańców Pomorza Zachodniego, [w:] Wszyscy jesteśmy tułaczami. Materiały opracowane z okazji obchodów Europejskich Dni Dziedzictwa 2007 w woj. zachodniopomorskim, red. M. Słomiński, Szczecin, s. 19-22.

Majewski Marcin. 2010. Pilgerzeichen auf Glocken in hinterpommerschen Kirchen, [w:] Wallfahrer aus dem Osten. Mittelalterliche Pilgerzeichen zwischen Ostsee, Donau und Seine. Beiträge der Tagung Perspektiven der Europäischen Pilgerzeichenforschung, 21. bis 24. April 2010 in Prag, red. H. Kühne, L. Lambacher, J. Hrdina, Europäische Wallfahrtsstudien, t. 10, Frankfurt am Main, s. 51-68.

Majewski Marcin. 2013. Stargard, Stare Miasto, dawny klasztor augustianów-eremitów, (ul. Klasztorna, Prządki, Wita Stwosza, Portowa), stan. 11 (AZP 32-10/167), „Stargardia”, t. 7, s. 351, 358. 
Majewski Marcin. 2017. Patryca, matryce i kafle renesansowe - nowe odkrycie z Pomorza Zachodniego, [w:] Gemma gemmarum: studia dedykowane Profesor Hannie Kóčce-Krenz, red. A. Różański, cz. 2, Poznań, s. 1365-1383.

Majewski Marcin, Rębkowski Marian, Simiński Rafał. 2016. Pielgrzymki pomorskie wśredniowieczu. Stan i perspektywy badań, „Przegląd Zachodniopomorski”, t. 31, nr 1, s. 129-168.

Majewski Marcin, Stań Karolina. 2015. Sprawozdanie wstępne z archeologicznych badań wyprzedzajacych na dawnym kwartale XXVIII część N-E, dz. geod. Nr 197/7, ul. Włosiennicza/Szewska (część historyczna). Stargard (maszynopis w archiwum Działu Archeologii MAH w Stargardzie).

Mills Nigel. 2003. Medieval artefacts. Catalogue and price guide, Witham, Essex.

Mitchiner Michael. 1986. Medieval pilgrim \& secular badges, London.

Paner Henryk. 2016. Gdańsk na pielgrzymkowych szlakach średniowiecznej Europy, Gdańsk.

Posse Otto. 1888. Die Siegel der Wettiner bis 1324 und der Landgrafen von Thüringen bis 1247, Leipzig.

Posse Otto. 1893. Die Siegel der Wettiner von 1324-1486 und Herzöge von Sachsen-Wittenberg und Kurfürsten von Sachsen aus Askanischem Geschlecht nebst einer Abhandlung über Heraldik und Sphragistik der Wettiner, Leipzig.

Rech Manfred. 2004. Gefundene Vergangenheit - Archäologie des Mittelalters in Bremen. Mit besonderer Berücksichtigung von Riga, Bremer Archäologische Blätter, t. 3, Bremen.

Rębkowski Marian. 1998. Znaki pielgrzymie, [w:] Archeologia średniowiecznego Kołobrzegu, t. 3, red. M. Rębkowski, Kołobrzeg, s. 223-227.

Rębkowski Marian. 2004. Pielgrzymki mieszkańców średniowiecznych miast poludniowego wybrzeża Battyku w świetle znalezisk znaków pątniczych. Wstęp do badań, „Kwartalnik Historii Kultury Materialnej”, R. LII, nr 2, s. 153-188.

Rębkowski Marian. 2014. Stone houses, glazed jugs and pilgrim badges. An archaeological contribution to the problem of the cultural unity of the hanseatic towns in the Baltic region, „Studia Maritima", t. 27, cz. 1, s. 5-23.

Rębkowski Marian, Rulewicz Marian. 2001. Czy mieszkańcy Szczecina pielgrzymowali w średniowieczu do Kolonii?, [w:] Instantia est mater doctrinae. Ksiega jubileuszowa prof. dr hab. Władysława Filipowiaka, red. E. Wilgocki, M. Dworaczyk, K. Kowalski, A. Porzeziński, S. Słowiński, Szczecin, s. 351-358.

Rębkowski Marian, Simiński Rafał. 2010. Pielgrzymki mieszkańców Pomorza Zachodniego do sanktuarium św. Teobalda $w$ Thann $w$ średniowieczu, [w:] Turystyka religijna, red. Z. Kroplewski, A. Panasiuk, Szczecin, s. 145-157.

Rymar Edward. 2015. Historia polityczna i społeczna Nowej Marchii w średniowieczu (do roku 1535), Gorzów Wlkp.

Sawicki Jakub, Wachowski Krzysztof. 2018. Akcesoria pielgrzymie i dewocjonalia, „Wratislavia Antiqua”, t. 23, cz. 2, s. 719-746.

Schäfer Cathrin. 2015. Greifswald, Hansestadt, Lkr. Vorpommern-Greifswald Fpl. 197, „Bodendenkmalpflege in Mecklenburg-Vorpommern”, t. 61, s. 334-339.

Spencer Brian. 2010. Pilgrim souvenirs and secular badges. Medieval finds from excavations in London, Medieval finds from excavation in London, t. 7, Woodbridge.

Stań Karolina. 2018. Stargard, Stare Miasto, ul. Szewska/Włosiennicza, stan. 11 (AZP 32-10/166), „Stargardia”, t. 12, s. 222-224.

Starnawska Maria. 2008. Świętych życie po życiu. Relikwie w kulturze religijnej na ziemiach polskich $w$ średniowieczu, Warszawa.

Streich Brigitte. 2003. Wettin, [w:] Höfe und Residenzen im spätmittelalterlichen Reich. Ein dynastisch-typographisches Handbuch, t. 15.I, red. W. Paravicini, Tübingen, s. 213-218.

Vauchez André. 1996. Święty, [w:] Człowiek średniowiecza, red. J. Le Goff, tłum. M. Radożycka-Paoletti, Warszawa, s. 389-430. 
Witkowska Aleksandra. 1995. Peregrinatio religiosa w średniowiecznej Europie, [w:] Peregrinationes. Pielgrzymki w kulturze dawnej Europy, red. H. Manikowska, H. Zaremska, Warszawa, s. 9-16.

Wittstock Jürgen. 1998. Der Bremer Pilgerzeichen-Fund, [w:] Der Jakobuskult in „Kunst “ und „,Literatur". Zeugnisse in Bild, Monument, Schrift und Ton, red. K. Herbers, R. Plötz, Tübingen, s. $85-107$.

Znamierowski Alfred. 2017. Heraldyka i weksykologia, red. i współpraca J.L. Kaczmarek, Warszawa.

Baza Kunera. http://www.kunera.nl/Kunerapage.aspx (dostęp 08.10.2018 r.).

\section{Mediaeval pilgrim badges and secular badges from Stargard}

The article is devoted to mediaeval pilgrim badges and secular badges found in recent years in the town of Stargard, in the former quarter XXVIII. The collection of six emblems includes two pilgrim badges from the sanctuaries in Maastricht and Cologne, one secular badge with the coat of arms of Brehna and three unidentified emblems made of an alloy of tin and copper. All those artefacts come from the oldest settlement strata of the chartered town.

The context of the finds indicates that the analysed pilgrim badges were devotional objects (parts of home altars?). So far eight pilgrim badges have been discovered in Western Pomerania; the two new finds significantly enrich this collection. Research on secular badges from that area is still at an early stage. 